\title{
Growth of Arbia goat kids in an intensive production system in Setif, Algeria
}

\author{
Desempenho do crescimento de cabritos Arbia sob sistema intensivo em Setif, Argélia
}

\author{
Hossem Sahraoui ${ }^{12_{\star}}$, Toufik Madani ${ }^{1}$, Hamza Benmakhlouf ${ }^{1}$, Mounira Bensalem ${ }^{3}$, Khaled Fantazi ${ }^{4}$, \\ Samir Bachir Suheil Gaouar ${ }^{5}$ \\ ${ }^{1}$ University of Setif 1, Faculty of Nature and Life Sciences, Setif, Algeria. *Author for correspondence: s_houss@yahoo.fr \\ ${ }^{2}$ National Center For Biotechnology Research, Constantine, Algeria \\ ${ }^{3}$ University of Skikda, Faculty of Science, Skikda, Algeria. \\ ${ }^{4}$ National Institute of Agronomic Research, El Harrach, Algeria. \\ ${ }^{5}$ University of Tlemcen, Chetouane Tlemcen, Algeria.
}

Submission: 14/11/2019 | Acceptance: 01/07/2020

\begin{abstract}
The growth of 81 indigenous Arbia goat kids reared in an intensive system in Setif in northeastern Algeria was observed between birth and 70 days of age. The kids were dam-raised during the first month and then provided with $150 \mathrm{~g} / \mathrm{head} /$ day of a total mixed ration and oat hay. The kids' live weights were assessed at fasting and at different ages: $0,10,21,30,42,60$, and 70 days. The average daily gains (ADG) were also calculated. Growth results were presented for all kids by sex and litter size. The average birth weight was $W_{0}=2.53 \pm 0.19 \mathrm{~kg}$, while the average weight at 70 days was $W_{70}=10.1 \pm 1.54 \mathrm{~kg}$, which correspond to an overall daily weight gain of $A D G_{0-70}=108 \pm 21 \mathrm{~g} /$ day. The study showed that birth weight was affected by litter size, while growth after birth was mainly affected by sex. Birth weights were similar between males and females, but males grew faster $(p<0.001)$ after birth. Single kids were heavier $(p<0.05)$ than twins at 70 days of age, which is the consequence of a heavier birth weight and a faster growth rate in the first 10 days after birth $\left(A D G_{0-10}\right)$. After 10 days, litter size did not affect $A D G$. Compared to other indigenous populations, Arbia goat kids demonstrated valuable growth potential for meat production.
\end{abstract}

KEYWORDS: Arbia breed, average daily gain, indigenous goat, live weight, zootechnical performance.

\section{RESUMO}

O crescimento de cabritos indígenas da Arbia criados sob um sistema de alto insumo foi investigado em 81 cabritos desde o nascimento até os 70 dias de idade na região de Setif, no nordeste da Argélia. A alimentação foi baseada no leite da mãe durante o primeiro mês de idade; em seguida, foram fornecidos $150 \mathrm{~g} / \mathrm{cabeça/dia}$ de uma ração mista total e feno de aveia. O peso vivo dos cabritos foi medido em jejum em diferentes idades: 0, 10 21, 30, 42, 60 e 70 dias, respectivamente. Também foram calculados os ganhos médios diários (GMD). Os resultados de desempenho de crescimento foram expressos para todos os cabritos, por sexo e tamanho da ninhada. $O$ peso médio ao nascer foi $P_{0}=2,53 \pm 0,19 \mathrm{~kg}$, enquanto o peso médio aos 70 dias foi $P_{70}=10,1 \pm 1,54 \mathrm{~kg}$, o que corresponde a um ganho de peso diário global $\mathrm{GMD}_{0-70}=108 \pm 21 \mathrm{~g} / \mathrm{dia}$. O estudo mostrou que o peso ao nascer foi afetado pelo tamanho da ninhada, enquanto o crescimento após o nascimento foi afetado principalmente pelo sexo. De fato, o peso ao nascer foi semelhante entre machos e fêmeas, mas após o nascimento os machos crescem mais rapidamente $(p<0,001)$. Os animais nascidos de partos simples eram mais pesados $(p<0,05)$ do que de partos gemelares aos 70 dias de idade, consequência do peso maior ao nascer e de uma taxa de crescimento mais rápida até os 10 dias de idade $\left(\mathrm{GMD}_{0-10}\right)$. A partir de 10 dias, o tamanho da ninhada não afetou o GMD. O desempenho dos cabritos da Arbia mostrou um potencial de crescimento valioso para a produção de carne quando comparado a outras populações de cabras indígenas.

PALAVRAS-CHAVE: raça Arbia, ganho médio diário, cabra indígena, peso vivo, desempenho zootécnico.

\section{INTRODUCTION}

Goat farming in Algeria coincides with the presence of other ruminants in rough, isolated rural areas and constitutes an important source of income for rural households. Goat flocks commonly rely only on pastoral and inedible resources, while feed supplements are provided exceptionally in the winter to ensure the animals' survival (SAHRAOUI et al. 2016). How the goats are reared is especially crucial to balancing 
and sustaining sheep and cattle farming in order to secure production systems.

The problem with the value chain for goats in Algeria is the increasing consumer demand for goat meat and milk from low-input pastoral production systems. In fact, indigenous goats are mainly reared in suckling systems for meat production. Efforts to develop high-input systems were made only for dairy production with selected imported breeds, without considering the potential of local animals. The only studies which have evaluated the production potential of indigenous populations were conducted in extensive systems (MADANI 2000, BELANTAR et al. 2018, DJOUZA \& CHEHMA 2018).

The Arbia goat population is the most widely dispersed goat population in Algeria, and while its morphometric characteristics and genetic diversity have been identified (FANTAZI et al. 2017, TEFIEL et al. 2018), its productivity and resource use efficiency are still relatively unknown.

Previous studies ( MAHGOUB et al. 2012, LAOUADI et al. 2018) have shown that meat production is still the main production type for the indigenous Arbia population, which is why growth is important to the profitability of farms. Therefore, this study investigates the pre-weaning growth of Arbia goat kids in highinput systems and the effect of sex and litter size.

\section{MATERIAL AND METHODS}

The experiment was conducted on the COOPSSEL Cooperative farm, located in Setif in the northeastern region of Algeria $\left(35^{\circ} 58^{\prime} \mathrm{N}, 5^{\circ} 32^{\prime} \mathrm{E}\right)$, which has a semi-arid climate and receives around $400 \mathrm{~mm}$ of rainfall per year.

The experiment involved 81 goat kids (Capra hircus) of the indigenous Arbia breed (Figure1) raised in a high-input, zero-grazing system.

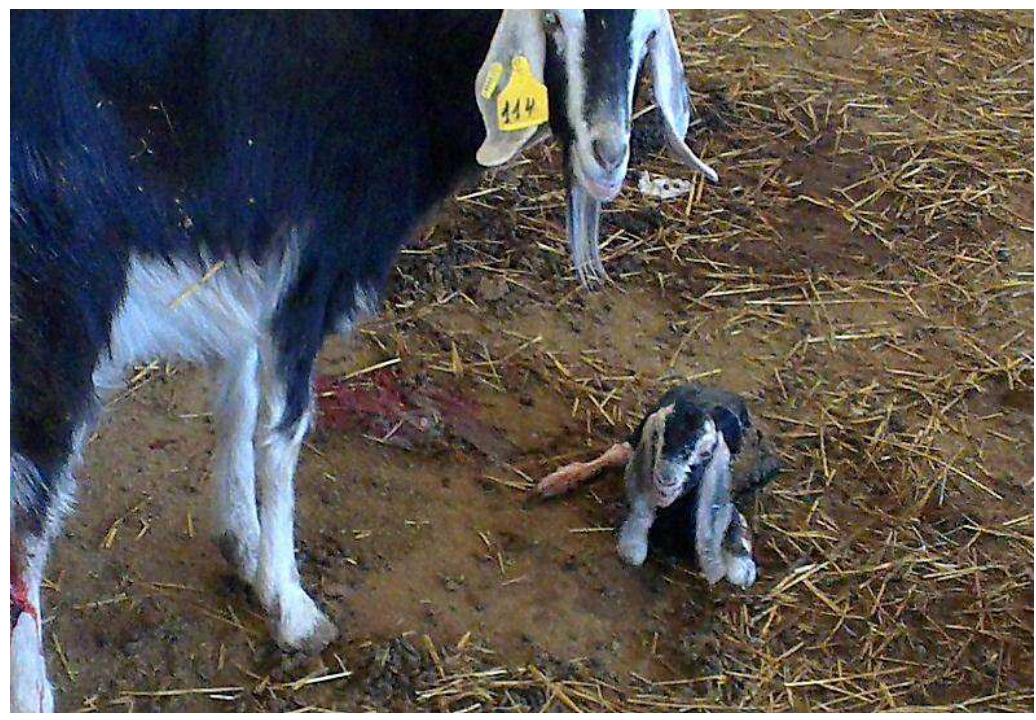

Figure 1. A doe from the flock just gave a birth.

The goat kids were dam-raised during the first month of age. As of the second month, oat hay and 150 $\mathrm{g} /$ head/day of a total mixed ration (TMR) were also provided (Table 1).

Table 2. Nutritional value of the total mixed ration.

\begin{tabular}{cccccccccc}
\hline & $\begin{array}{c}\text { Dry Matter } \\
(\mathrm{kg})\end{array}$ & $\mathrm{UFL}^{1}$ & $\mathrm{UFV}^{2}$ & $\mathrm{PDIN}^{3}(\mathrm{~g})$ & $\mathrm{PDIE}^{4}(\mathrm{~g})$ & $\mathrm{Ca}(\mathrm{g})$ & $\mathrm{P}(\mathrm{g})$ & $\begin{array}{c}\text { Crude fibre } \\
(\mathrm{g})\end{array}$ & $\mathrm{LFU}^{5}$ \\
\hline $\begin{array}{c}1 \mathrm{~kg} \text { of } \\
\text { TMR }\end{array}$ & 0.79 & 0.67 & 0.60 & 90.22 & 81.01 & 1.34 & 1.98 & 12 & 0.37 \\
\hline
\end{tabular}

'UFL: feed unit for lactation; ${ }^{2} \mathrm{UFV}$ : feed unit for meat production; ${ }^{3} \mathrm{PDIN}$ : protein digested in the small intestine allowed by nitrogen; ${ }^{4} \mathrm{PDIE}$ : Protein digested in the small intestine allowed by energy; ${ }^{5} \mathrm{LFU}$ : lactating fill unit: fill ability of food in lactating animals expressed in French system.

The experiment was performed based on the protocol for suckling lamb (NAVES et al. 2005, TIPHINE et al. 2005, BEN HAMOUDA \& REKIK 2012). The following information was recorded: the kid's sex (male or female); litter size (single or twin); and the kid's weight (W) at the ages of $01021,30,42,60$, and 70 days. The average daily gain (ADG) was then calculated for 0-10 days, 10-21 days, 21-30 days, 30-42 days, 42-60 
days, 60-70 days, and 0-70 days. The kids were weighed in the morning before feeding on a $30 \mathrm{~kg}$ weighing scale (5 g precision).

The XLSTAT software (version 2014) was used for statistical analysis. For descriptive statistics and a comparison of means, the Student's t-test was used to analyze LW (live weight, kg) and ADG (average daily gain, g/day), based on sex and litter size. Correlation tests were performed to assess the relationship between LW and the different growth periods of the kids. A significance level of $5 \%$ was accepted.

\section{RESULTS AND DISCUSSION}

Effect of sex: The weight characteristics of Arbia goat kids are presented in Table 2. Results showed that birth weight $\left(W_{0}\right)$ was similar $(p>0.05)$ between males and females $(2.56 \pm 0.2 \mathrm{~kg}$ and $2.5 \pm 0.17 \mathrm{~kg}$, respectively). The birth weight for males was similar to the values reported by DJOUZA \& CHEHMA (2018) for the same breed and by CHENTOUF et al. (2006) for the indigenous goat of Northern Morocco. However, compared to previous studies, the birth weight was higher for females in this study $\left(\mathrm{W}_{0}=2.1 \pm 0.6\right.$ and $\mathrm{W}_{0}=$ $2.37 \pm 0.34$, respectively). The average $W_{0}$ was higher than the weights recorded for the Draa goat $\left(W_{0}=2.3\right.$ $\mathrm{kg}$ ) reared in the oases of Morocco (IBNELBACHYR et al. 2007), the black and red goats of Maradi $\left(\mathrm{W}_{0}=\right.$ 1.95 and $1.82 \mathrm{~kg}$, respectively) in Niger (MARICHATOU et al. 2002), the Lubumbashi goat $\left(\mathrm{W}_{0}=1.75 \mathrm{~kg}\right.$ ) of Congo (KALENGA et al. 2015), and the Creole goat $\left(W_{0}=1.73 \mathrm{~kg}\right.$ ) (ALEXANDRE et al. 1997). The average $\mathrm{W}_{0}$ was lower than the weights registered for the selected European breeds Saanen $\left(\mathrm{W}_{0}=3.22 \mathrm{~kg}\right)$, Alpine $\left(\mathrm{W}_{0}=3.65 \mathrm{~kg}\right)$, and Toggenburg $\left(\mathrm{W}_{0}=3.38 \mathrm{~kg}\right)$ (McMANUS et al. 2008) and the Damascus breed $\left(\mathrm{W}_{0}=3.92\right.$ kg) (GÜNEY et al. 2006).

At 10 days of age, the difference between the sexes was significant $(p<0.05)$; the males weighed more than the females $(4.06 \pm 0.57 \mathrm{~kg}$ vs. $3.54 \pm 0.69 \mathrm{~kg})$. The weight at 10 days was significantly higher for both sexes than for the Creole goat (ALEXANDRE et al. 1997). In comparison with CHENTOUF et al. (2006), our results showed a similar weight for males but a lower weight for females $(4.1 \pm 0.8 \mathrm{Vs} 3.3 \pm 0.9 \mathrm{Kg})$. Moreover, for weights $W_{21}, W_{30}, W_{42}, W_{60}$, and $W_{70}$, males registered greater values than females $(p<0.001)$. We also found that $W_{30}$ and $W_{70}$ in both sexes were higher than those observed in the Creole breed (ALEXANDRE et al. 1997), in the northern goat of Morocco (CHENTOUF et al. 2006), and in the Arbia population reared in extensive systems (DJOUZA \& CHEHMA 2018).

Figure 2 shows that males and females were born with the same weight but that males grow faster. A similar pattern was also reported for the West African dwarf goat and the Croatian multi-colored goat (MIOČ et al. 2011, BIRTEEB et al. 2015), while CHENTOUF et al. (2006) reported that males had a greater birth weight than females in the indigenous goat population of northern Morocco.

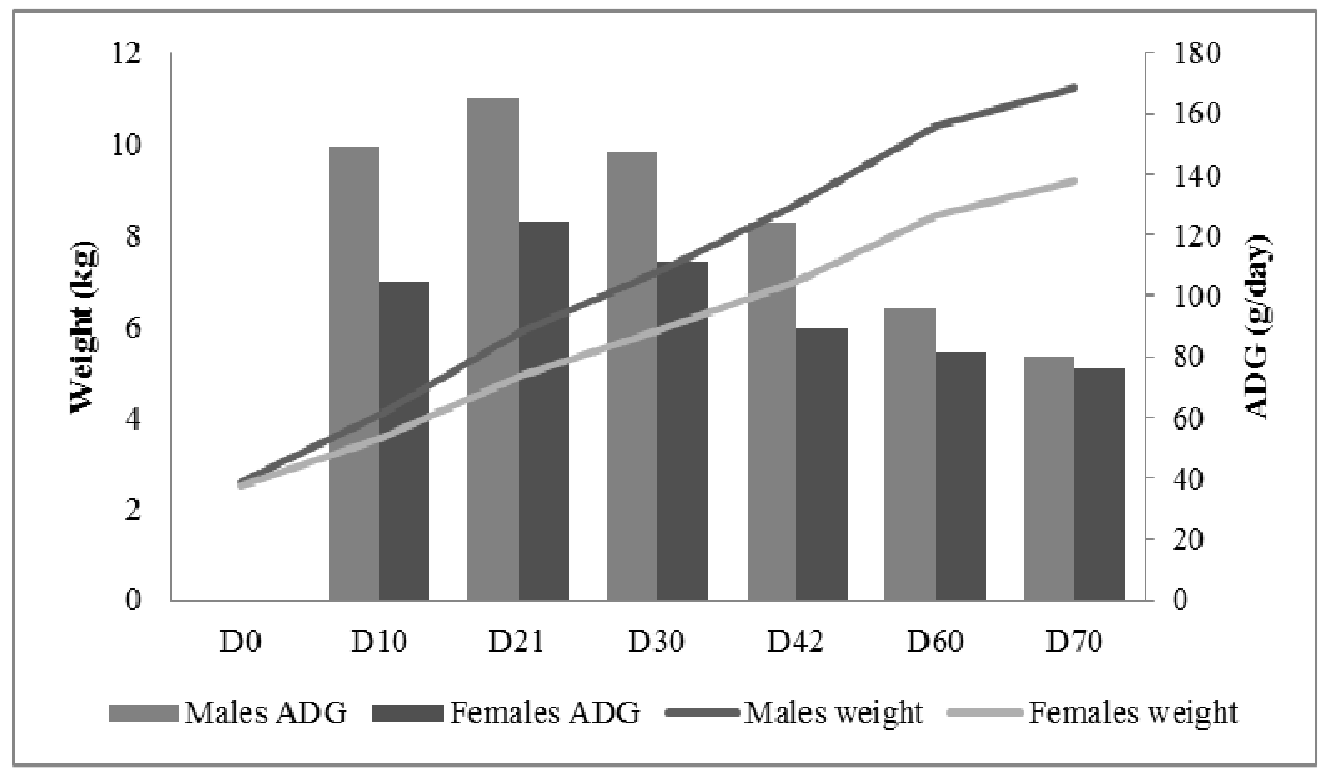

Figure 2. Weight gain progress and average daily gains for males and females based on age.

Based on Figure 2 and Table 3, males had higher ADGs than females $(p<0.05)$, except for $A D G_{60-70,}$ which decreased significantly for males and was closer to the value for females at this age. On average, the overall ADG (0-70 days) was greater for males ( $p<0.001)$ than for females $(124 \pm 15 \mathrm{vs.} 96 \pm 17 \mathrm{~g} /$ day).

Table 2. Progress of the kids' average daily gains (g/day) by sex. 


\begin{tabular}{|c|c|c|c|c|c|c|c|c|}
\hline & $\mathrm{N}$ & $\mathrm{ADG}_{0-10}$ & $\mathrm{ADG}_{10-21}$ & $\mathrm{ADG}_{21-30}$ & $\mathrm{ADG}_{30-42}$ & $\mathrm{ADG}_{42-60}$ & $\mathrm{ADG}_{60-70}$ & $\mathrm{ADG}_{0-70}$ \\
\hline Males & 36 & $149 \pm 48$ & $165 \pm 35$ & $147 \pm 37$ & $124 \pm 34$ & $96 \pm 13$ & $80 \pm 13$ & $124 \pm 15$ \\
\hline Fema & 45 & $\underset{* \star \star *}{105 \pm 62}$ & $\underset{* \star *}{125 \pm 45}$ & $111 \pm \underset{* \star \star}{11 \pm 3}$ & $\underset{* \star * *}{89 \pm 34}$ & $81_{* \star *} \pm 19$ & $\begin{array}{c}76 \pm 18 \\
\text { NS }\end{array}$ & $\underset{* \star *}{96 \pm 17}$ \\
\hline Mean & 81 & $125 \pm 60$ & $143 \pm 45$ & $127 \pm 41$ & $105 \pm 38$ & $88 \pm 18$ & $78 \pm 16$ & $108 \pm 21$ \\
\hline
\end{tabular}

N: sample's size; ADG: Average Daily Gain; NS= not significant; ${ }^{* * *}=p<0.001$.

The overall ADGs recorded in our study are comparable to the values reported by CHENTOUF et al. (2006) in high-input systems and higher than the values provided by DJOUZA \& CHEHMA (2018) for the same breed in low-input systems. Therefore, for faster growth, a balanced diet is vital for both the lactating does and goat kids.

Effect of litter size: The effect of litter size on the kids' birth weight was clearly demonstrated in our study. Single kids were heavier than twins (Table 4). Our results are consistent with findings by MADIBELA et al. (2002) and ZELEKE (2007) for the Tswana breed of Botswana and the Somali breed of Ethiopia, respectively. The effect of litter size on birth weight is due to the twins' small size and low weight in the uterus resulting from the nutrients shared between fetuses (ROBINSON et al. 1977, LAWRENCE \& FOWLER 2002). This difference in birth weight influenced weight at different stages of growth. This was also the case for the Creole goat (CHEMINEAU et al. 1985) and the Croation multi-colored goat (MIOČ et al. 2011). The weights of single and twin goat kids were different $(p<0.001)$ between $W_{0}$ and $W_{10}$ and partly recovered at $\mathrm{W}_{21}$ until weaning (Table 3 ).

Table 3. Kids' weight (kg) gain progress by litter size.

\begin{tabular}{lcccccccc}
\hline & $\mathrm{N}$ & $\mathrm{W}_{0}$ & $\mathrm{~W}_{10}$ & $\mathrm{~W}_{21}$ & $\mathrm{~W}_{30}$ & $\mathrm{~W}_{42}$ & $\mathrm{~W} 60$ & $\mathrm{~W} 70$ \\
\hline Single & 60 & $2.57 \pm 0.17$ & $3.92 \pm 0.68$ & $5.51 \pm 0.99$ & $6.67 \pm 1.13$ & $7.95 \pm 1.30$ & $9.56 \pm 1.35$ & $10.34 \pm 1.36$ \\
Twin & 21 & $2.40 \pm 0.16$ & $3.34 \pm 0.50$ & $4.87 \pm 0.83$ & $5.96 \pm 1.16$ & $7.15 \pm 1.56$ & $8.64 \pm 1.81$ & $9.40 \pm 1.83$ \\
& & $\star \star \star$ & $\star \star * *$ & $\star$ & $\star$ & $\star$ & $*$ & \\
Mean & 81 & $2.53 \pm 0.19$ & $3.77 \pm 0.68$ & $5.34 \pm 0.99$ & $6.49 \pm 1.18$ & $7.74 \pm 1.41$ & $9.32 \pm 1.53$ & $10.10 \pm 1.54$
\end{tabular}

$\mathrm{N}$ : sample's size; W: Weight at studied ages; NS= not significant; ${ }^{* \star}=p<0.001^{*}=p<0.05 ;{ }^{* \star *}=p<0.001$.

Table 4. Progress of the kids' average daily gains ( $g /$ day) by litter size.

\begin{tabular}{lcccccccc}
\hline & $\mathrm{N}$ & $\mathrm{ADG}_{0-10}$ & $\mathrm{ADG}_{10-21}$ & $\mathrm{ADG}_{21-30}$ & $\mathrm{ADG}_{30-42}$ & $\mathrm{ADG}_{42-60}$ & $\mathrm{ADG}_{60-70}$ & $\mathrm{ADG}_{0-70}$ \\
\hline Singles & 60 & $135 \pm 60$ & $144 \pm 47$ & $130 \pm 36$ & $107 \pm 37$ & $90 \pm 15$ & $78 \pm 15$ & $111 \pm 19$ \\
Twins & 21 & $94 \pm 50$ & $139 \pm 41$ & $121 \pm 52$ & $99 \pm 42$ & $83 \pm 24$ & $77 \pm 20$ & $100 \pm 25$ \\
& & $\star *$ & $\mathrm{NS}$ & $\mathrm{NS}$ & $\mathrm{NS}$ & $\mathrm{NS}$ & $\mathrm{NS}$ & $\star$ \\
Mean & 81 & $125 \pm 60$ & $143 \pm 45$ & $127 \pm 41$ & $105 \pm 38$ & $88 \pm 18$ & $78 \pm 16$ & $108 \pm 21$ \\
\hline
\end{tabular}

$\mathrm{N}$ : sample's size; ADG: Average Daily Gain; $N S=$ not significant; ${ }^{*}=p<0.05 ;{ }^{* *}=p<0.01$.

Growth rate in the pre-weaning period was affected by litter size and was higher for single kids than for twins $(p<0.05)$. These results are consistent with the data provided by MADIBELA et al. (2002), ZELEKE (2007), and BUSHARA et al. (2013) for the Tswana goats of Botswana, the Somali goats of Ethiopia, and the Taggar goats of Sudan, respectively. For the Blended breed of Tanzania, LYATUU et al. (1992) also reported that after birth, single kids had enough milk to develop before weaning, while twins had to fight over their mother's milk.

Table 5 shows that the difference between single and twin goat kids is significant only for ADG $_{0-10}$ $(p<0.01)$; however, it was significant enough to influence $A D G_{0-70}$ (overall), which was more significant for single kids $(p<0.05)$.

Figure 3 demonstrates that single kids experienced faster growth $(p<0.01)$ than twin kids during the first 10 days, after which the ADGs of the twin kids increased rapidly during $A D G_{10-21}$ to catch up to the single kids' growth rate until finally reaching the same pace of growth. This, however, allowed single kids to maintain a higher weight than twin kids.

According to Tables 3 and 4 and Figure 3, the difference in weight at 70 days of age can be attributed to the differences in birth weight based on sex combined with a faster growth rate for single kids during the first 10 days after birth. 


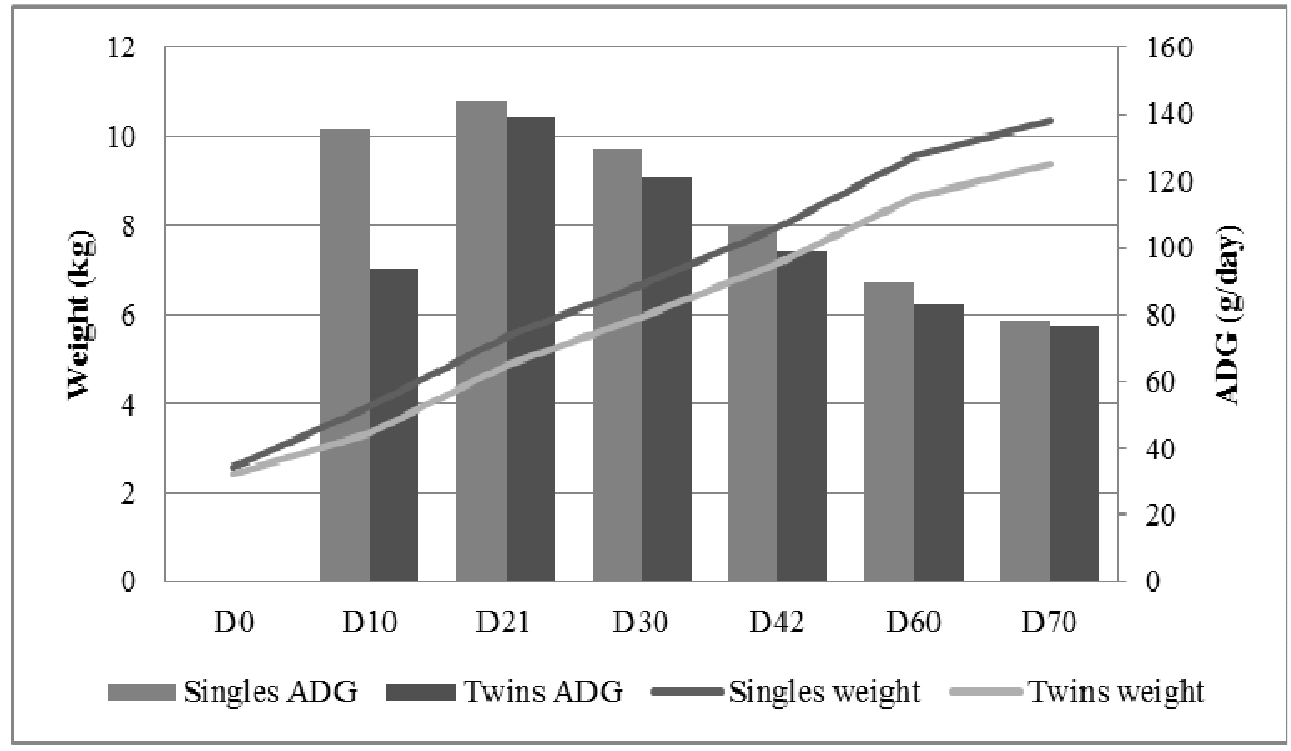

Figure 1 . Weight gain progress and average daily gains for single and twin goat kids.

Relationship between the weights at different ages: The growth of goat kids is influenced by several factors that are genetic and/or environmental (ANDRIES 2013, MEZA-HERRERA et al. 2014). Table 5 illustrates that the birth weight's effect on weight at different ages is moderate and regressive. The correlation between $W_{0}$ and $W_{10}$ is $r_{w 0-W 10}=0.56$, while the correlation between $W_{0}$ and $W_{70}$ is $r_{w 0-W 70}=0.40$.

Table 5. Relationship between live weights in different growth phases of Arbia goat kids.

\begin{tabular}{cccccccc}
\hline Variables & $\mathrm{W}_{0}$ & $\mathrm{~W}_{10}$ & $\mathrm{~W}_{21}$ & $\mathrm{~W}_{30}$ & $\mathrm{~W}_{42}$ & $\mathrm{~W}_{60}$ & $\mathrm{~W}_{70}$ \\
\hline $\mathrm{W}_{0}$ & 1.00 & 0.56 & 0.52 & 0.50 & 0.43 & 0.42 & 0.40 \\
$\mathrm{~W}_{10}$ & & 1.00 & 0.88 & 0.81 & 0.69 & 0.64 & 0.60 \\
$\mathrm{~W}_{21}$ & & & 1.00 & 0.96 & 0.87 & 0.82 & 0.79 \\
$\mathrm{~W}_{30}$ & & & & 1.00 & 0.95 & 0.91 & 0.90 \\
$\mathrm{~W}_{42}$ & & & & & 1.00 & 0.98 & 0.97 \\
$\mathrm{~W}_{60}$ & & & & & & 1.00 & 0.99 \\
$\mathrm{~W}_{70}$ & & & & & & & 1.00 \\
\hline
\end{tabular}

W: Weight at studied ages; The correlations are different from 0 at a significance level alpha $=0.001$.

Table 5 shows that the environment had the most important effect on the goat kids' growth. Their growth is strongly related to the mothers' milk production (quality and quantity), especially during the first 40 days (ALEXANDRE 1991). This means that the effect of their birth weight, which is affected by litter size, on their weight at 70 days of age is moderate. In fact, over time, kids express their genetic potential and can catch up with "compensatory growth." This phenomenon has been observed in multiple litters, as reported in the study on five Mexican breeds by MEZA-HERRERA et al. (2014), who indicated that litter size has no significant effect on weaning weight (13 $\mathrm{kg}$ in this case).

\section{CONCLUSION}

The Arbia goat has adapted well to controlled breeding conditions and expresses interesting growth patterns compared to several other African breeds (the Draa goat from Morocco, the Maradi from Niger, or the Lubumbashi from Congo). However, as with other goat breeds and other small ruminants, there are many variable factors that modify these growth patterns, including litter size and the sex of the kid, whose effects have been clearly demonstrated in our study.

Our study also showed the importance of a balanced diet in reaching target weights (marketable) more quickly in order to optimize the farm's productivity.

For better animal use and enhanced productivity, improvements can be made. These improvements range from the management of food and livestock farming practices to genetic improvement, which is perfectly desirable in the case of the Arbia goat breed as it has exhibited good growth potential. 


\section{REFERENCES}

ALEXANDRE G. 1991. Croissance pré-sevrage des chevreaux en Guadeloupe. Revue d'Élevage et de Médecine Véterinaire des Pays Tropicaux. Spécial: 57-62.

ALEXANDRE G et al. 1997. Performances zootechniques de la chèvre Créole allaitante de Guadeloupe. Bilan de 20 ans dans un élevage expérimental de l'INRA. INRA Productions Animales 10: 7-20.

ANDRIES KM. 2013. Growth and Performance of Meat Goat Kids from Two Seasons of Birth in Kentucky. Sheep \& Goat Research Journal 28: 16-20.

BELANTAR I et al. 2018. Phenotypic characterization of local goat population in western Algeria (Wilaya of Relizane) with morpho metric measurements and milk analysis. Genetics and Biodiversity Journal 2: 55-66.

BIRTEEB PT et al. 2015. Growth performance of West African dwarf goats reared in the transitional zone of Ghana. Asian Journal of Animal Sciences 9: 370-378.

BUSHARA I et al. 2013. Effect of sex of kids and litter size on Taggar goat Kids performance. Archiva Zootechnica 16: 514.

CHEMINEAU $P$ et al. 1985. Mortalité, poids à la naissance et croissance de chevreaux créoles nés en élevage semiintensif. Annales de Zootechnie 34: 193-204.

CHENTOUF $M$ et al. 2006. Évaluation des performances de production de la chèvre locale du nord du Maroc. ALAWAMIA 3: 137-152.

DJOUZA L \& CHEHMA A. 2018. Production characteristics of Arabia goats in Biskra Wilayah, Algeria. Livestock Research for Rural Development 30: 7.

FANTAZI K et al. 2017. Characterization of Morphological Traits Algerian indigenous goats by multivariate analysis. Genetics and Biodiversity Journal 1: 20-30.

GÜNEY O et al. 2006. Milk production, reproductive and growth performances of Damascus goats under northern Cyprus conditions. Small Ruminant Research 65: 176-179.

BEN HAMOUDA M \& REKIK M. 2012. Contrôle de croissance des ovins allaitants en Tunisie, perte de précision sur le calcul des performances à âge type selon un protocole simplifié alternatif au protocole officiel. Revue d'élevage et de médecine vétérinaire des pays tropicaux. 65: 41-47.

IBNELBACHYR M et al. 2007. Performances zootechniques des petits ruminants dans les oasis du sud marocain Small ruminant performances in the southern Moroccan oasis. Renc. Rech. Ruminants 14: 437.

KALENGA HK et al. 2015. Goat breeding in Lubumbashi (DRC): 2. Analyse de la croissance pré et post-sevrage de chevreaux locaux. Livestock Research for Rural Development 27: 12.

LAOUADI M et al. 2018. A basic characterization of small-holders' goat production systems in Laghouat area, Algeria. Pastoralism 8: 24-32.

LAWRENCE TLJ \& FOWLER VR. 2002. Growth of Farm Animals 2.ed. Cambridge: CAB International.

LYATUU ETR et al. 1992. Some production parameters of Blended goats in semi-arid regions of Tanzania. Arusha: Proceedings of the Second Biennial Conference of the African Small Ruminant Research Network, AICC. p.241-245.

MADANI T. 2000. Elevage caprin dans le nord-est de l'Algérie. In: GRUNER L \& CHABERT Y (Ed.). 'Proc. 7éme conférence international sur les caprins'. Tours: Poitiers. p.351-353.

MADIBELA OR et al. 2002. Effect of supplementation on reproduction of wet season kidding Tswana goats. South African Journal of Animal 32: 14-22.

MAHGOUB O et al. 2012. Goat meat production, composition, and quality. 1.ed. London: CABI.

MARICHATOU H et al. 2002. Performances zootechniques des caprins au Niger: étude comparative de la chèvre rousse de Maradi et de la chèvre à robe noire dans la zone de Maradi. Revue d'élevage et de Médicine Vétérinaire des Pays Tropicaux 55: 79-84.

McMANUS C et al. 2008. Growth of Saanen, Alpine and Toggenburg Goats in the Federal District, Brazil : Genetic and Environmental factors. Ciência Animal Brasileira 9: 68-75.

MEZA-HERRERA CA et al. 2014. Effect of breed and some environmental factors on body weights till weaning and litter size in five goat breeds in Mexico. Small Ruminant Research 121:215-219.

MIOČ B et al. 2011. Study on birth weight and pre-weaning growth of Croatian multicolored goat kids. Veterinarski Arhiv 81: 339-347.

NAVES M et al. 2005. Application de la méthodologie du contrôle de performances ovin viande à la chèvre Créole de Guadeloupe. In: Rencontre Rech. Ruminants 2005 12ème Journées. Paris: 3R. p.350.

ROBINSON JJ et al. 1977. Studies on reproduction in prolific ewes - Growth of the products of conception. The Journal of Agricultural Science 88: 539-552.

SAHRAOUI $\mathrm{H}$ et al. 2016. Le développement d'une filière lait caprin en régions de montagne: un atout pour un développement régional durable en Algérie. Options Méditerranéennes. The value chains of Mediterranean sheep and goat products. Organisation of the industry, marketing strategies, feeding and production systems 115: 677-681.

TEFIEL H et al. 2018. Genetic characterization of four Algerian goat breeds assessed by microsatellite markers. Small Ruminant Research 160: 65-71.

TIPHINE L et al. 2005. Proposition d'allègement du contrôle de performances en ovins allaitants. In: Rencontre Rech. Ruminants 2005 12ème Journées. Paris: 3R. p.349

ZELEKE ZM. 2007. Environmental influences on pre-weaning growth performances and mortality rates of extensively managed Somali goats in Eastern Ethiopia. Livestock Research for Rural Development 19: 12.

Rev. Ciênc. Agrovet., Lages, SC, Brasil (ISSN 2238-1171) 